\title{
YOLO and Self-Control
}

\author{
Hana Song \\ Department of Child Psychology and Education, Sungkyunkwan University, Seoul, Korea
}

욜로와 자기통제

송하나

성균관대학교 아동청소년학과

최근 많은 청소년들과 젊은이들이 "인생은 한번 사는 것이 다(You Only Live Once [YOLO]; Drake, 2011, track 19)"라는 의미로 현재를 충실히 즐기는 삶의 방식인 욜로(YOLO)에 열광하고 있다. 어떤 사람들은 욜로를 현재의 중요성을 강조 하는 라틴어 구절 “카르페 디엠(Carpe Diem; Horace, n.d.)" 의 현대적 표현으로 생각한다. 그러나 많은 사람들이 욜로를 미래에 대한 희망을 저버리는 무책임한 태도라고 여기는 것 같다.

욜로는 후회나 주저함, 또는 두려움 없는 삶을 강조하기 때문에, 어떠한 욕구를 즉각적으로 만족하고자 하는 성향과 관련된다고 알려져 있다. 따라서, '당장 원하는 대로 먹고, 말 하고, 행동하고, 돈을 쓰고, 즐기는 것'이 오로지 일차적인 쾌 락만을 추구하는 무모한 행동으로 보일 수 있다. 이러한 점 에서, 욜로는 자기 통제 개념과 대치되는 것처럼 보인다.

자기 통제는 욕구의 일방적인 억제만을 의미하는 개념이 아니다. 보다 넓은 의미에서 자기 통제는 자신의 감정, 의도, 생각, 능력 등을 정확히 인식하고, 성취하려는 개인의 목표 나 사회적 요구에 따라 이것들을 효율적으로 조절하는 능력 을 말한다(Bandura, 1988, 1991; Kopp, 1982). 이러한 점에서 통제보다 조절을 더 적절한 용어로 생각하는 학자들도 있다. 또한 자기 통제는 적절한 노력과 책략을 사용하여 개인의 마 음과 생각을 사회가 수용하는 방식으로 표현할 수 있는 능력 을 포함한다(Thompson, 1994).

Corresponding Author: Hana Song, Editor-in-Chief Department of Child Psychology and Education, Sungkyunkwan University, 25-2, Sungkyunkwan-Ro, Jongno-Gu, Seoul 03063, Korea E-mail: jni4ever@skku.edu
자기 통제는 욜로와 다른 동기 체계에 기반을 두는 것 같 다. 사람들은 개인에 따라 특정한 종류의 욕구를 충족하는 데 특히 높은 동기를 가진다. 욜로는 보다 즉각적이고 현저하 게 나타나는 보상에 의해 동기화되는 것 같다. 예를 들어, 돈 을 아끼지 않고 비싼 명품을 사는데 소비하는 것은 소유의 욕 구와 다른 사람들의 부러움을 얻는 욕구를 동시에 충족한다. 반면, 자기 통제는 더 높은 수준의 성공을 이루거나 조화로운 사회 관계를 맺는 것 같이 다소 시간이 걸리는 성취에 동기화 되는 것으로 보인다(Bandura, 1988; Fishbach \& Shah, 2006). 한마디로, 자기 통제는 장기적 목표의 성취를 지향한다.

동서양의 오랜 문헌들에서 자기 통제의 중요성을 언급하 는 부분을 찾는 것은 어렵지 않다. 공자는 논어에서 "극기복 례(克己復禮; The Analects of Confucius, n.d.)”라 하여 자신의 감정과 욕망을 극복하고 행동을 바로 하는 것이 사람의 도리 인 인(仁)을 행하는 일이라 하였다. 성경 잠언서에는 "노하기 를 더디하는 자는 용사보다 낫고 자기의 마음을 다스리는 자 는 성을 빼앗는 자보다 나으니라(Proverb 16:32 New Korean Revised Version)"는 구절이 있다. 이처럼 자기 통제는 지역과 문화를 초월하여 강조되어온 미덕이다.

그렇다면 자기 통제는 왜 이렇게 강조되는 것일까? 아 마 가장 중요한 이유는 자기 통제가 개인의 성공적인 삶, 궁극적 행복, 삶의 만족, 그리고 사회적 안녕을 이루는데 결정적 요인이기 때문일 것이다. 지난 수십 년 간 많은 연

(C) The Korean Association of Child Studies

This is an Open Access article distributed under the terms of the Creative Commons Attribution Non-Commercial License (http:// creativecommons.org/licenses/by-nc/4.0) which permits unrestricted noncommercial use, distribution, and reproduction in any medium, provided the original work is properly cited. 
구들(e.g., Baumeister \& Exline, 2000; Crescioni, Ehrlinger, Alquist, Conlon, Baumeister, Schatschneider, \& Dutton, 2011; Normandeau \& Guay, 1998; Tangney, Baumeister, \& Boone, 2004)이 자기 통제가 아동, 청소년, 성인의 인지 및 사회정서 발달, 학교와 직업 성취, 신체적, 정신적 건강, 가족 관계, 및 삶의 만족에 긍정적인 영향을 미친다는 것을 보여주고 있다. 이번 호에 실린 몇몇 연구들 역시 자기 통제와 밀접한 관련 이 있는 의도적 통제를 다루고 있다. 특히, 이번 호를 읽을 때 의도적 통제의 종단적 영향력을 눈 여겨 보기 바란다.

그러나 인간발달에서 욜로가 어떠한 역할을 하는지에 대 해서는 아직 수행된 연구가 적어 결론을 내리기 어렵다. 일 반적으로 많은 사람들이 욜로가 전생애 발달 과업을 성공적 으로 수행하는데 걸림돌이 될 것이라고 생각하는 것 같다. 하지만 현재의 만족 추구에서 오는 즐거움이 어떠한 상황에 서는 이후 삶을 더욱 적극적이고 활발하게 살아가게 하는 추 동력으로 작용할 수 있다는 점을 주목할 필요가 있다. 특히, 욜로가 지향하는 현재의 삶을 즐기는 태도는 완전히 소진되 어 무기력하거나 삶의 동기가 바닥난 사람들에게 예상외의 긍정적 결과를 가져다 줄 수 있다.

즐거움의 경험은 욜로 뿐 아니라 자기 통제에서도 중요하 다. 자기 통제가 단지 고통스러운 인내의 과정이기만 하다면, 어느 누구도 자기 통제를 오래 지속하기 어렵다. 자기 통제는 긍정적인 정서적 피드백을 통해 자발적으로 동기화되는 즐 거운 경험이 되어야 한다. 욜로와 자기 통제는 다른 가치와 지향성을 가진다. 그러나 이 두 가지가 인간의 행복과 안녕의 증진을 위해 상보적으로 공존하여 시너지효과를 낼 수 있는 지 이후 학술적 탐색을 통해 밝힐 필요가 있을 것이다.

Many adolescents and young adults are enthusiastic about the concept of YOLO (You Only Live Once; Drake, 2011, track 19), which represents a lifestyle that fully enjoys current life. Some people think YOLO is a modernized expression of Carpe diem (seize the day; Horace, n.d.), but others seem to believe that it is a hopeless and irresponsible attitude that disregards a future life.

YOLO seems to be related to the tendency to satisfy desires immediately because it emphasizes living a life without regrets, hesitation, or fear. Thus, "to eat, talk, act, spend money, and enjoy as one wants now" can be viewed as reckless behaviors to seek only primary pleasure. In this perspective, YOLO runs contrary to the concept of selfcontrol, which relates to delay gratification.

Self-control (or regulation) is not a concept that simply involves the suppression of one's desires. Rather, it is the ability to correctly recognize one's emotions, intentions, thoughts, and competencies and to effectively modify and regulate them according to personal goals or social demands (Bandura, 1988, 1991; Kopp, 1982). Selfcontrol also involves the ability to express such things in socially acceptable ways using appropriate strategies and efforts (Thompson, 1994).

It is believed that self-control is based on different motivation from YOLO. People are motivated to satisfy various types of desires. The concept of YOLO is likely to be motivated by an immediate and salient reward, be it either physiological or psychological. For example, buying expensive luxury goods can be a means to satisfy both desires of possession and getting envious attention from others. On the other hand, self-control seems to be motivated by achieving a higher level of success or building a harmonious social relationship, which takes a relatively long time (Bandura, 1988; Fishbach \& Shah, 2006). In a word, self-control can be oriented to satisfy a long-term goal.

It is not difficult to see the importance of self-control in old scriptures and classic literatures from the East and West. For example, in the Analects, Confucius says, “To subdue one's self and return to propriety is perfect virtue."(克已復禮; The Analects of Confucius, n.d.). In the Proverbs of The Bible, it says "Better a patient person than a warrior, one with self-control than one who takes a city." (Proverb 16:32 New Korean Revised Version). Thus, selfcontrol is a virtue across regions and cultures.

So why is self-control so emphasized? Perhaps it is because it is a critical component of the success, happiness, life-satisfaction, and well-being of individuals. In the last few decades, many studies (e.g., Baumeister \& Exline, 2000; Crescioni, Ehrlinger, Alquist, Conlon, Baumeister, Schatschneider, \& Dutton, 2011; Normandeau \& Guay, 1998; Tangney, Baumeister, \& Boone, 2004) have revealed that self-control positively 
affects cognitive and socio-emotional outcomes, school and job achievement, physical and mental health, family relationships, and the life satisfaction of children, adolescents, and adults. Several articles published in this issue of the KJCS examine effortful control, which is closely related to self-control. I recommend that you pay attention to the longitudinal influence of effortful control while reading this issue.

It is difficult to draw conclusions about the role of YOLO in human development since little systematic research has been conducted about it. Many people seem to consider YOLO to be a stumbling block that interrupts the successful achievement of developmental tasks throughout one's lifespan. However, it is important to note that the experiences of pleasure through the immediate satisfaction of desires can also be a driving force for people to live more actively and energetically in certain contexts. In particular, the attitude of enjoying one's present life in accordance with the concept of YOLO could bring positive results to people who have become lethargic and drained of motivation.

The experience of pleasant feelings is related to selfcontrol as well as YOLO. No one will be able to control themselves for a long time if self-control was simply a process of painful suppression and patience. It should be an enjoyable and joyful experience through self-motivated and positive emotional feedback. YOLO and self-control have different values and orientations, but future research should investigate the possibility that these two ideals can coexist in complementary ways to promote individual happiness and well-being.

Hana Song, Editor-in-Chief of the Korean Journal of Child Studies.

\section{Conflict of Interest}

No potential conflict of interest relevant to this editorial was reported.

\section{References}

\section{In English}

Bandura, A. (1988). Self-regulation of motivation and action through goal systems. In V. Hamilton, H. G. Bower, \& N. H. Frijda (Eds.). NATO Science Series D: Cognitive perspectives on emotion and motivation (pp. 37-61). Boston: Kluwer Academic Publisher.

Bandura, A. (1991). Social cognitive theory of self-regulation. Organizational Behavior and Human Decision Processes, 50(2), 248-287. doi:10.1016/0749-5978(91)90022-L

Baumeister, R. F., \& Exline, J. J. (2000). Self-control, morality, and human strength. Journal of Social and Clinical Psychology, 19(1), 29-42. doi:10.1521/jscp.2000.19.1.29

Crescioni, A. W., Ehrlinger, J., Alquist, J. L., Conlon, K. E., Baumeister, R. F., Schatschneider, C., \& Dutton, G. R. (2011). High trait self-control predicts positive health behaviors and success in weight loss. Journal of Health Psychology, 16(5), 750-759. doi:10.1177/1359105310390247

Drake (2011). The motto [Produce by T-Minus]. On Take Care [CD]. New York: Universal.

Fishbach, A., \& Shah, J. Y. (2006). Self-control in action: Implicit dispositions toward goals and away from temptations. Journal of Personality and Social Psychology, 90(5), 820-832. doi:10.1037/0022-3514.90.5.820

Kopp, C. B. (1982). Antecedents of self-regulation: A developmental perspective. Developmental Psychology, 18(2), 199-214. doi:10.1037/0012-1649.18.2.199

Normandeau, S., \& Guay, F. (1998). Preschool behavior and firstgrade school achievement: The mediational role of cognitive self-control. Journal of Educational Psychology, 90(1), 111-121. doi:10.1037/0022-0663.90.1.111

Tangney, J. P., Baumeister, R. F., \& Boone, A. L. (2004). High selfcontrol predicts good adjustment, less pathology, better grades, and interpersonal success. Journal of Personality, 72(2), 271-324. doi: 10.1111/j.0022-3506.2004.00263.x

Thompson, R. A. (1994). Emotion regulation: A theme in search of definition. Monographs of the Society for Research in Child Development, 59(2-3), 25-52. doi:10.1111/j.1540-5834.1994. tb01276.x
Hana Song http://orcid.org/0000-0002-7745-7303

\section{ORCID}

